\title{
Analisa Pemahaman Metode Demonstrasi Terhadap Implementasi Skil Lab Pemeriksaan Kehamilan (ANC) Mahasiswi D III Kebidanan
}

\author{
Widhya Ayu Maharani, Erma Retnaningtyas, Lingga Kusuma Wardani* \\ Institut Ilmu Kesehatan STRADA Indonesia \\ Corresponding author: Lingga Kusuma Wardani (linggakusumawardani@gmail.com) \\ Received: December, 16 2019; Accepted: January, 19 2020; Published: March, 152020
}

\begin{abstract}
ABSTRAK
Keterampilan Klinis (clinical skill) pada profesi kebidanan merupakan hal yang mutlak di butuhkan. Keterampilan merupakan kecakapan motorik yang di landasi pengetahuan dan sikap afektif yang baik. Desain penelitian menggunakan pendekatan cross sectional. Populasi dan sampel penelitian ini adalah semua mahasiswi D III kebidanan semester 3. Dengan menggunakan teknik total sampling sebanyak 43 responden. Variabel independen metode demonstrasi, variabel dependen skil lab pemeriksaan kehamilan (ANC). Instrumen penelitian ini menggunakan lembar kuesioner dan check list, dianalisa menggunakan uji Regresi Ordinal. Berdasarkan hasil penelitian didapatkan analisa derajat kemaknaan $\alpha=0,005$ didapatkan hasil uji statistik Regresi Ordinal. Dengan nilai signifikan Sig.(2-tailed) 0,000. Yang berarti H0 ditolak, H1 diterima, sehingga ada pengaruh metode demonstrasi terhadap implementasi skil lab pemeriksaan kehamilan (ANC) mahasiswi D III kebidanan STIKes Surya Mitra Husada Kediri. Saat proses pembelajaran metode demonstrasi, mahasiswa kurang aktif bertanya jika ada penyampaian materi yang kurang jelas saat dosen mempersilahkan bertanya.
\end{abstract}

Kata Kunci: Metode Demonstrasi, Skills Lab, Mahasiswa

This is an open-acces article distributed under the terms of the Creative Commons Attribution-ShareAlike 4.0 International License.

\section{PENDAHULUAN}

Keterampilan klinis (clinical skill) pada profesi kebidanan merupakan hal yang mutlak di butuhkan. Keterampilan tersebut merupakan kecakapan motorik yang dilandasi oleh pengetahuan dan sikap afektif yang baik. Pelayanan kebidanan tidak dapat dijalankan dengan baik dan optimal jika hanya mengandalkan pemahaman keilmuan tanpa adanya keterampilan tersebut. bahkan keterampilan klinis bagi bidan harus terinternalisasi dalam dirinya, sehingga dalam melakukan tindakan dan penatalaksanaan kasus yang sesungguhnya terjadi otomatis karena keilmuan dan keterampilan tersebut telah menyatu (embedded) dengan perilaku profesionalnya. Untuk mencapai kemampuan klinis yang baik tersebut sangat di perlukan latihan yang optimal bagi calon bidan selama menjalani pendidikan, baik dari segi kualitas ataupun kuantitas (Jurnal Pendidikan Kedokteran Indonesia, 2016). 
Proses belajar dalam mematangkan kemampuan klinis dengan real patients akhir-akhir ini menjadi tantangan sendiri bagi mahasiswa kebidanan dan profesi kesehatan lainnya karena adanya perubahan paradigma dalam pelayanan kesehatan dari sisi etika, hukum, dan penyalagunaan teknologi kesehatan. Pada satu sisi pelayanan kepada masyarakat (pasien) haruslah pelayanan yang aman (safe) dan berkualitas (high quality), tetapi pada sisi lainnya proses pendidikan haruslah tetap memberikan kesempatan yang cukup kepada mahasiswi untuk belajar dalam mangasah keterampilan klinisnya. Atas dasar inilah, proses pembelajaran keterampilan klinis berkembang dengan menggunakan teknik simulasi dengan bantuan alat atau model (Jurnal Pendidikan Kedokteran Indonesia, 2016).

Latihan keterampilan klinis dengan simulasi menggunakan alat atau model (skil lab) dapat memenuhi dua kebutuhan dan tantangan pada pelayanan kesehatan dan pendidikan sekaligus. Latihan keterampilan pada model dapat meningkatkan keamanan dan menurunkan kesalahan yang dilakukan pada latihan dengan pasien pada tahap proses pendidikan selanjutnya. Hal ini dapat dicapai karena setiap keterampilan prosedural, pada tahap awal diberikan pelatihan pada mahasiswa dengan menggunakan model, hingga mahasiswa telah memahami konsep dengan kecakapan pada level tertentu. Dengan kemampuan pada level tersebut sudah cukup aman jika dilakukan proses latihan pada pasien dengan supervisi. Pelatihan keterampilan klinis dengan simulasi menggunakan alat atau model telah terbukti mampu meningkatkan kecakapan mahasiswa mulai dari keterampilan sederhana hingga yang lebih kompleks, pelatihan keterampilan klinis meningkatkan kompetensi mahasiswa pada kepaniteraan klinik (Jurnal Pendidikan Kedokteran Indonesia, 2016).

Menurut Djamarah (2015) Prestasi belajar siswa adalah hasil belajar yang dicapai mahasiswa ketika mengikuti dan mengerjakan tugas dan kegiatan perkuliahan di kampus. Prestasi belajar yang dicapai oleh mahasiswa dapat dipengaruhi oleh beberapa faktor, baik yang berasal dari diri mahasiswa (faktor internal) maupun dari luar mahasiswa (faktor eksternal). Faktor internal diantaranya adalah minat, bakat, motivasi, tingkat intelegensi. Sedangkan faktor eksternal diantaranya adalah faktor metode pembelajaran. Ada beberapa metode pembelajaran yang dapat diterapkan dalam proses pembelajaran diantaranya adalah metode ceramah, metode resitasi, metode ekperimen, metode diskusi, metode demonstrasi, metode problem solving, metode tanya jawab, metode simulasi, metode inquery dan discovery, dan metode latihan dan praktek.

Menurut Sumiati (2015), Metode pembelajaran demonstrasi merupakan pertunjukan atau peragaan. Dalam metode pembelajaran demonstrasi dilakukan pertunjukan sesuai proses, berkenaan dengan materi pelajaran. Hal ini juga dapat dilakuakan oleh dosen/guru atau orang luar yang di undang ke kelas dan proses yang didemonstrasikan di ambil dari obyek yang sebenarnya.

Dari sisi inilah memungkinkan mahasiswa lebih dapat mengerti dan memahami meteri yang diajarkan sehingga dapat meningkatkan semangat belajar mahasiswa. Bagi mahasiswa metode pembelajaran seperti demonstrasi akan mendorong mahasiswa untuk lebih memperhatikan mata kuliah yang diajarkan.

Mahasiswa D III Kebidanan STIKes Surya Mitra Husada Kediri mengatakan bahawa metode pembelajaran demonstrasi sangat efektif dalam skil lab, karena dianggap proses pembelajaran akan lebih menarik sebab mereka tidak hanya mendengar, tetapi juga melihat peristiwa yang terjadi. Dengan cara mengamati secara langsung mahasiswa akan memiliki kesempatan untuk membandingkan antara teori dan kenyataan. Mahasiswa juga menyadari bahwa metode pembelajaran demonstrasi ini memerlukan persiapan yang matang. Sebab tanpa persiapan yang matang seperti mempelajari materi yang akan di demonstrasikan di lab, pembelajaran demonstrasi ini bisa gagal sehingga dapat menyebabkan metode ini tidak efektif lagi. 
Dari Penelitian awal yang dilakukan di STIKes Surya Mitra Husada Kediri Program Studi D-III Kebidanan nilai mahasiswa dalam pembelajaran Asuhan Kebidanan Kehamilan dari 39 mahasiswa angkatan 2016 Tahun Ajaran 2016/2017 semester III, yang mendapat nilai A sebanyak 4 mahasiswa (10\%), nilai AB sebanyak 16 mahasiswa (41\%), nilai B sebanyak 16 mahasiswa (41\%), nilai BC sebanyak 3 mahasiswa (8\%). Hal ini menunjukkan bahwa kemampuan skil lab pemeriksaan kehamilan mahasiswa sebagian besar dalam kategori baik. Mata kuliah Asuhan Kebidanan Kehamilan juga merupakan suatu syarat mata kuliah yang harus lulus untuk mengambil mata kuliah di semester selanjutnya.

Dari data diatas, diharapkan pembelajaran skil lab menggunakan metode demonstrasi ini mampu membuat mahasiswa lebih memahami pembelajaran yang di berikan menggunakan metode demonstrasi dan hasil yang didapatkan mahasiswa sebagian besar adalah nilai A, karena di lihat dari data di atas mahasiswa yang mendapatkan nilai A sangat sedikit sebanyak 4 orang. Adapun tujuan dari penelitian ini adalah untuk mengetahui Pengaruh Dari Metode Pembelajaran Demonstrasi Terhadap Implementasi Skill Lab Pemeriksaan Kehamilan (ANC) Mahasiswi D III Kebidanan .

\section{METODE}

Desain penelitian ini adalah penelitian Analitik yang bertujuan untuk mengungkapkan hubungan korelatif dua variabel yaitu menghubungkan antara variable independen dan variable dependen (Notoatmodjo, 2010).

Desain penelitian menggunakan pendekatan cross sectional. Populasi dan sampel penelitian ini adalah semua mahasiswi D III kebidanan semester 3. Dengan menggunakan teknik total sampling sebanyak 43 responden. Variabel independen metode demonstrasi, variabel dependen skil lab pemeriksaan kehamilan (ANC). Instrumen penelitian ini menggunakan lembar kuesioner dan check list, dianalisa menggunakan uji Regresi Ordinal.

\section{HASIL PENELITIAN DAN}

\section{Karakteristik Subyek}

Tabel 1. Metode Demonstrasi terhadap implementasi skil lab pemeriksaan kehamilan (ANC) mahasiswi D III Kebidanan

\begin{tabular}{|c|c|c|c|}
\hline No. & Metode Demonstrasi & Jumlah & \% \\
\hline 1 & Baik & 41 & 96 \\
\hline 2 & Cukup & 1 & 2 \\
\hline 3 & Kurang & 1 & 2 \\
\hline \multicolumn{2}{|c|}{ Jumlah } & 43 & 100 \\
\hline
\end{tabular}

Sumber : Data Primer 13 Mei 2019

Berdasarkan tabel 1 diketahui bahwa sebagian besar responden menyampaikan bahwa metode demonstrasi terhadap implementasi skil lab pemeriksaan kehamilan (ANC) pada kategori baik yaitu sebesar $41(96 \%)$ responden.

Tabel 2. Implementasi Skil lab pemeriksaan kehamilan (ANC) mahasiswi D III Kebidanan STIKes Surya Mitra Husada Kediri

\begin{tabular}{|c|l|c|c|}
\hline No. & \multicolumn{1}{|c|}{$\begin{array}{c}\text { Skil Lab Pemeriksaan Kehamilan } \\
\text { (ANC) }\end{array}$} & Jumlah & \% \\
\hline 1 & Sangat Baik & 25 & 58 \\
\hline 2 & Antara Baik dengan Sangat Baik & 18 & 42 \\
\hline 3 & Baik & 0 & 0 \\
\hline
\end{tabular}




\begin{tabular}{|c|l|c|c|}
\hline 4 & Antara Cukup Dan Baik & 0 & 0 \\
\hline 5 & Cukup & 0 & 0 \\
\hline \multicolumn{2}{|c|}{ Jumlah } & $\mathbf{4 3}$ & $\mathbf{1 0 0}$ \\
\hline
\end{tabular}

Sumber : Data Primer 13 Mei 2019

Berdasarkan tabel 2 diketahui bahwa sebagian besar responden menyampaikan bahwa implementasi skil lab pemeriksaan kehamilan (ANC) pada kategori sangat baik yaitu sebanyak 25 orang $(58 \%)$ responden.

\section{HASIL UJI STATISTIK}

Tabel 2. Analisa pengaruh pemahaman metode demonstrasi terhadap implementasi skil lab pemeriksaan kehamilan (ANC) mahasiswi D III kebidanan STIKes Surya Mitra Husada Kediri

\begin{tabular}{|c|c|c|c|c|c|}
\hline \multicolumn{5}{|c|}{ Model Fitting Information } & \multirow{5}{*}{$\begin{array}{l}\quad \mathrm{Be} \\
\text { rdasarka } \\
\mathrm{n} \text { tabel } 2 \\
\text { hasil uji } \\
\text { statistik } \\
\text { dengan }\end{array}$} \\
\hline Model & $\begin{array}{c}-2 \text { Log } \\
\text { Likelihood }\end{array}$ & Chi-Square & Df & Sig. & \\
\hline Intercept Only & 44,233 & & & & \\
\hline Final & 4,004 & 40,229 & 6 &, 000 & \\
\hline \multicolumn{5}{|c|}{ Link function: Logit. } & \\
\hline
\end{tabular}

menggunakan Regresi Ordinal didapatkan nilai Sig. (2-tailed) $=0,000<0,05$, maka H0 di tolak. Hal ini berarti $\mathrm{H} 1$ di terima sehingga ada pengaruh yang signifikan antara pemahaman metode demonstrasi terhadap implementasi skil lab pemeriksaan kehamilan (ANC) mahasiswi D III kebidanan STIKes Surya Mitra Husada Kediri.

\section{PEMBAHASAN}

Analisa Pemahaman Metode Demonstrasi Terhadap Implementasi Skil Lab Pemeriksaan Kehamilan (ANC) Mahasiswi D III Kebidanan Stikes Surya Mitra Husada Kediri.

Berdasarkan tabel 4.1 diketahui bahwa sebagian besar responden menyampaikan bahwa metode demonstrasi terhadap implementasi skil lab pemeriksaan kehamilan (ANC) pada kategori baik yaitu sebesar $41(96 \%)$ responden.

Menurut Sumiati (2015), Metode pembelajaran demonstrasi merupakan pertunjukan atau peragaan. Dalam metode pembelajaran demonstrasi dilakukan pertunjukan sesuai proses, berkenaan dengan materi pelajaran. Hal ini juga dapat dilakuakan oleh dosen/guru atau orang luar yang di undang ke kelas dan proses yang didemonstrasikan di ambil dari obyek yang sebenarnya.

Dari sisi inilah memungkinkan mahasiswa lebih dapat mengerti dan memahami meteri yang diajarkan sehingga dapat meningkatkan semangat belajar mahasiswa. Bagi mahasiswa metode pembelajaran seperti demonstrasi akan mendorong mahasiswa untuk lebih memperhatikan mata kuliah yang diajarkan.

Jika ditinjau dari hasil penyebaran kuesioner ada beberapa responden yang mendapat nilai AB yaitu sebanyak 18 (42\%), salah satu indikator yang menyebabkan responden tersebut mendapat nilai $\mathrm{AB}$ yaitu mahasiswa kurang aktif bertanya jika ada penyampaian materi yang kurang jelas saat dosen mempersilahkan bertanya. Sebaiknya sebagai mahasiswa harus lebih aktif bertanya jika pada saat penyampaian materi dari dosen ada yang tidak di pahami. Karena basic mahasiswa kesehatan sangat mempengaruhi kualitas hidup manusia.

Dari hasil penelitian diketahui pada Tabel 4.3 bahwa dari 43 responden sebagian besar mengatakan bahwa metode demonstrasi dengan kategori baik ada $25(61,0 \%)$ responden yang 
berpengaruh terhadap implementasi skil lab pemeriksaan kehamilan (ANC) mahasiswi D III kebidanan STIKes Surya Mitra Husada Kediri.

Pembelajaran klinik sebagai salah satu strategi pembelajaran perlu mendapat perhatian yang serius karena dapat membelajarkan aspek kognitif, afektif dan psikomotor secara bersama (Zainuddin, 2016).

Tujuan pembelajaran skill laboratory adalah untuk menyamakan pembelajaran dan evaluasi keterampilan klinik dengan menggunakan alat penilaian yang sama bagi semua mahasiswa, meningkatkan sikap mahasiswa dalam memberi pelayanan pada pasien (Mahmoud, 2016).

Berdasarkan fakta dan teori di atas maka dapat di simpulkan bahwa seorang pendidik dalam menyajikan materi skil lab menggunakan metode demonstrasi, dapat mendorong peserta didik untuk lebih memperhatikan mata kuliah yang diajarkan. Sehingga peserta didik dapat memperoleh nilai yang memuaskan pada saat skil lab di adakan.

\section{Pengaruh Pemahaman Metode Demonstrasi Terhadap Implementasi Skil Lab Pemeriksaan Kehamilan (ANC) Mahasiswi D III Kebidanan STIKes Surya Mitra Husada Kediri}

Berdasarkan tabel 4.4 hasil uji statistik dengan menggunakan Regresi Ordinal didapatkan nilai Sig. (2-tailed) $=0,000<0,05$, maka H0 di tolak. Hal ini berarti H1 di terima sehingga ada pengaruh yang signifikan antara pemahaman metode demonstrasi terhadap implementasi skil lab pemeriksaan kehamilan (ANC) mahasiswi D III kebidanan STIKes Surya Mitra Husada Kediri.

Keterampilan klinis (clinical skil) pada profesi kebidanan merupakan hal yang mutlak di butuhkan. Keterampilan tersebut merupakan kecakapan motorik yang dilandasi oleh pengetahuan dan sikap afektif yang baik. Pelayanan kebidanan tidak dapat dijalankan dengan baik dan optimal jika hanya mengandalkan pemahaman keilmuan tanpa adanya keterampilan tersebut. bahkan keterampilan klinis bagi bidan harus terinternalisasi dalam dirinya, sehingga dalam melakukan tindakan dan penatalaksanaan kasus yang sesungguhnya terjadi otomatis karena keilmuan dan keterampilan tersebut telah menyatu (embedded) dengan perilaku profesionalnya. Untuk mencapai kemampuan klinis yang baik tersebut sangat di perlukan latihan yang optimal bagi calon bidan selama menjalani pendidikan, baik dari segi kualitas ataupun kuantitas (Jurnal Pendidikan Kedokteran Indonesia, 2016).

Latihan keterampilan klinis dengan simulasi menggunakan alat atau model (skil lab) dapat memenuhi dua kebutuhan dan tantangan pada pelayanan kesehatan dan pendidikan sekaligus. Latihan keterampilan pada model dapat meningkatkan keamanan dan menurunkan kesalahan yang dilakukan pada latihan dengan pasien pada tahap proses pendidikan selanjutnya. Hal ini dapat dicapai karena setiap keterampilan prosedural, pada tahap awal diberikan pelatihan pada mahasiswa dengan menggunakan model, hingga mahasiswa telah memahami konsep dengan kecakapan pada level tertentu. Dengan kemampuan pada level tersebut sudah cukup aman jika dilakukan proses latihan pada pasien dengan supervisi. Pelatihan keterampilan klinis dengan simulasi menggunakan alat atau model telah terbukti mampu meningkatkan kecakapan mahasiswa mulai dari keterampilan sederhana hingga yang lebih kompleks, pelatihan keterampilan klinis meningkatkan kompetensi mahasiswa pada kepaniteraan klinik (Jurnal Pendidikan Kedokteran Indonesia, 2016).

Latihan keterampilan klinis dengan simulasi menggunakan alat atau model (skil lab) dapat memenuhi dua kebutuhan dan tantangan pada pelayanan kesehatan dan pendidikan sekaligus. Latihan keterampilan pada model dapat meningkatkan keamanan dan menurunkan kesalahan yang dilakukan pada latihan dengan pasien pada tahap proses pendidikan selanjutnya. Hal ini dapat dicapai karena setiap keterampilan prosedural, pada tahap awal diberikan pelatihan pada mahasiswa dengan menggunakan model, hingga mahasiswa telah 
memahami konsep dengan kecakapan pada level tertentu. Dengan kemampuan pada level tersebut sudah cukup aman jika dilakukan proses latihan pada pasien dengan supervisi.

Pelatihan keterampilan klinis dengan simulasi menggunakan alat atau model telah terbukti mampu meningkatkan kecakapan mahasiswa mulai dari keterampilan sederhana hingga yang lebih kompleks, pelatihan keterampilan klinis meningkatkan kompetensi mahasiswa pada kepaniteraan klinik (Jurnal Pendidikan Kedokteran Indonesia, 2016).

Oleh karena itu dengan metode demonstrasi kebutuhan peserta didik lebih dapat terpusatkan pada materi yang di berikan, kesalahan-kesalahan yang terjadi bila materi itu di ceramahkan dapat diatasi melalui pengamatan dan contoh konkrit. Sehingga kesan yang diterima peserta didik lebih mendalam selanjutnya memberikan motivasi yang kuat untuk peserta didik agar lebih giat belajar. Jadi, dengan metode demonstrasi peserta didik dapat partisipasi aktif, dan memperoleh pengalaman langsung, dapat mengembangkan kecakapannya, serta mendapatkan nilai yang memuaskan saat skil lab di adakan.

\section{KESIMPULAN}

1. Berdasarkan hasil tabulasi silang antar variabel, Tabel 4.3 menunjukkan bahwa dari 43 responden sebagian besar mengatakan bahwa metode demonstrasi dengan kategori baik ada $25(61,0 \%)$ responden yang berpengaruh terhadap implementasi skil lab pemeriksaan kehamilan (ANC) mahasiswi D III kebidanan STIKes Surya Mitra Husada Kediri.

2. Berdasarkan hasil uji statistik dengan menggunakan Regresi Ordinal didapatkan nilai Sig. (2-tailed) $=0,000<0,05$, maka $\mathrm{H} 0$ di tolak. Hal ini berarti H1 di terima sehingga ada pengaruh yang signifikan antara pemahaman metode demonstrasi terhadap implementasi skil lab pemeriksaan kehamilan (ANC) mahasiswi D III kebidanan STIKes Surya Mitra Husada Kediri.

\section{Saran}

1. Bagi Responden

Dari hasil penelitian mahasiswa bisa digunakan sebagai acuan untuk meningkatkan minat belajar keterampilan skil lab pemeriksaan kehamilan (ANC) mahasiswi D III Kebidanan STIKes Surya Mitra Husada Kediri.

2. Bagi Institusi Pendidikan

Pembimbing harus mempunyai kemampuan dalam managemen waktu pelaksanaan Skill $L a b$ agar pelaksanaan sesuai dengan rancangan. Hasil penelitian ini dapat digunakan sebagai sumber pustaka, acuan penelitian, sebagai bahan evaluasi, dan wacana ke depan bagi STIKes Surya Mitra Husada Kediri dalam meningkatkan kualitas pembelajaran khususnya keterampilan laboratorium (Skill Lab).

3. Bagi Peneliti Selanjutnya

Hasil penelitian ini dapat digunakan sebagai referensi bagi peneliti selanjutnya apabila peneliti selanjutnya ingin meneliti pemahaman demonstrasi terhadap implementasi skil lab pemeriksaan kehamilan (ANC).

\section{KEPUSTAKAAN}

Ahmadi, A. dan Widodo, S. 2015. Psikologi Belajar. Jakarta: Rhineka Cipta.

Arifin, Z. 2011. Evaluasi Instruksional (Prinsip-Teknik-Prosedur). Bandung: Remaja Rosdakarya

Aswan Z. 2014. Strategi Belajar Mengajar.Jakarta: Rineka Cipta

Clark, N. 1991. Managing Personal Learning and Change, A Trainer's Guide. London: McGraw-Hill Book Company

Djamarah, Syaiful, B. dan Aswan, Z. 2016. Strategi Belajar Mengajar. Jakarta. Rineka Cipta. 
Djamarah, Syaiful, B. 2012. Prestasi Belajar dan Kompetensi Guru. Surabaya: Usaha Nasional.

Hudoyo, H., 2015. Interaksi Belajar Mengajar. Jakarta: Departernen P \& K, P3K.

Kusmiayati, yuni. 2009. Perawatan Ibu Hamil (Asuhan Ibu Hamil). Yogyakarta: Fitramaya

Mappa, S., dkk., 2017. Belajar dan Mengajar. Jakarta : Proyek PLPTK Ditjen Dikti Depdikbud.

Marmi. 2012. Asuhan Kebidanan Pada Ibu Hamil edisi 7. Yogyakarta : Penerbit Pelajar .2014. Asuhan Kebidanan Pada Ibu Hamil. Yogyakarta : Penerbit Pelajar

Notoadmodjo, 2012. Metodologi Penelitian Kesehatan. Jakarta : Rineka Cipta

Pasaribu dan Simanjuntak. 2016. Proses Belajar Mengajar, Bandung: Penerbit Tarsito Bandung.

Peraturan pemerintah Republik Indonesia no 60 tahun 1999

Pusat Bahasa, Departemen Pendidikan Nasional. 2015. Kamus Besar Bahasa Indonesia. Jakarta: Balai Pustaka.

Roestiyah. 2016. Strategi Belajar Mengajar, PT. Aneka Cipta, Jakarta.

Sardiman, A.M. 2013. Metode Belajar siswa, PT. Raia Grafinao Persada, Jakarta.

Slameto, W. 2015. Belajar dan Faktor Yang Mempengaruhi, Jakarta: Penerbit Reneka Cipta.

Slameto, W. 2014. Belajar dan Faktor-faktor Yang Mempengaruhi, Penerbit Rineka Cipta, Jakarta.

Sudjana, N. 2011. Dasar-dasar Proses Belajar Mengajar. Bandung: Sinar Baru.

Sugiono, 2012. Memahami Penelitian Kuantitatif. Bandung : Alfabeta.

Sumiati dan Asra. 2008. Metode Pembelajaran, CV. Wacana Prima, Bandung.

Suparno, P. 1987. Teori Perkembangan Kognitif Jean Piaget. Yogyakarta: Kanisus

Surakhmad, W. 2012. Pengantar Interaksi Belajar Mengajar, Dasar dan Teknik Pengajaran. Bandung : Tarsito

. 2013. Pengantar Interaksi Belajar Mengajar, Dasar dan Teknik Pengajaran.

Bandung. Tarsito

Suryabrata, S. 2016, Pengembangan Tes Hasil Belajar, Jakarta: PT Raja Grafindo Persada.

Syaiful, B. 2012 . Strategi Belajar Mengajar.Jakarta: Rineka Cipta

Usman, U. 2015. Menjadi Guru Proposional. Bandung Remaja Rosda Karya. 